\title{
A novel large animal model of smoke inhalation-induced acute respiratory distress syndrome
}

\author{
Premila D. Leiphrakpam¹ , Hannah R. Weber ${ }^{1}$, Andrea McCain², Roser Romaguera Matas², \\ Ernesto Martinez Duarte ${ }^{3}$ and Keely L. Buesing ${ }^{1 *}$ (D)
}

\begin{abstract}
Background: Acute respiratory distress syndrome (ARDS) is multifactorial and can result from sepsis, trauma, or pneumonia, amongst other primary pathologies. It is one of the major causes of death in critically ill patients with a reported mortality rate up to $45 \%$. The present study focuses on the development of a large animal model of smoke inhalation-induced ARDS in an effort to provide the scientific community with a reliable, reproducible large animal model of isolated toxic inhalation injury-induced ARDS.
\end{abstract}

Methods: Animals ( $n=21$ ) were exposed to smoke under general anesthesia for 1 to $2 \mathrm{~h}$ (median smoke exposure $=0.5$ to $1 \mathrm{~L}$ of oak wood smoke) after the ultrasound-guided placement of carotid, pulmonary, and femoral artery catheters. Peripheral oxygen saturation $\left(\mathrm{SpO}_{2}\right)$, vital signs, and ventilator parameters were monitored throughout the procedure. Chest $\mathrm{x}$-ray, carotid, femoral and pulmonary artery blood samples were collected before, during, and after smoke exposure. Animals were euthanized and lung tissue collected for analysis $48 \mathrm{~h}$ after smoke inhalation.

Results: Animals developed ARDS $48 \mathrm{~h}$ after smoke inhalation as reflected by a decrease in $\mathrm{SpO}_{2}$ by approximately $31 \%, \mathrm{PaO}_{2} / \mathrm{FiO}_{2}$ ratio by approximately $208(50 \%)$, and development of bilateral, diffuse infiltrates on chest x-ray. Study animals also demonstrated a significant increase in IL-6 level, lung tissue injury score and wet/dry ratio, as well as changes in other arterial blood gas (ABG) parameters.

Conclusions: This study reports, for the first time, a novel large animal model of isolated smoke inhalation-induced ARDS without confounding variables such as cutaneous burn injury. Use of this unique model may be of benefit in studying the pathophysiology of inhalation injury or for development of novel therapeutics.

Keywords: Smoke inhalation, ARDS, Large animal model, Toxic inhalation injury, Hypoxia, Hypoxemia

\section{Introduction}

Acute respiratory distress syndrome (ARDS) is a serious pulmonary condition in critically ill patients with a reported mortality rate ranging from $30-45 \%[1,2]$. There has been no significant change in the mortality rate since 1994 [2]. ARDS can be caused by a variety of

\footnotetext{
*Correspondence: keely.buesing@unmc.edu

${ }^{1}$ Department of Surgery, College of Medicine, University of Nebraska Medical Center, Omaha, NE 68198-3280, USA

Full list of author information is available at the end of the article
}

direct and indirect injuries to the lung, including sepsis, trauma, pneumonia and smoke inhalation/burn injury [3-5]. Understanding the pathophysiological and molecular mechanisms of ARDS is critical for the development of novel therapeutic strategies for ARDS.

ARDS was coined by Ashbaugh et al. in 1967 to describe an acute onset of tachypnea, hypoxemia, and loss of compliance after a variety of insults [6]. The most current consensus definition for ARDS in clinical setting was published in 2012 as the Berlin criteria [7]. The

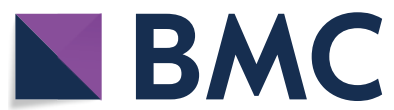

(c) The Author(s) 2021. Open Access This article is licensed under a Creative Commons Attribution 4.0 International License, which permits use, sharing, adaptation, distribution and reproduction in any medium or format, as long as you give appropriate credit to the original author(s) and the source, provide a link to the Creative Commons licence, and indicate if changes were made. The images or other third party material in this article are included in the article's Creative Commons licence, unless indicated otherwise in a credit line to the material. If material is not included in the article's Creative Commons licence and your intended use is not permitted by statutory regulation or exceeds the permitted use, you will need to obtain permission directly from the copyright holder. To view a copy of this licence, visit http://creativecommons.org/licenses/by/4.0/. The Creative Commons Public Domain Dedication waiver (http://creativeco mmons.org/publicdomain/zero/1.0/) applies to the data made available in this article, unless otherwise stated in a credit line to the data. 
Berlin criteria base categorization of ARDS on level of hypoxemia measured by the $\mathrm{PaO}_{2} / \mathrm{FiO}_{2}$ (arterial oxygen partial pressure/fraction of inspired oxygen) ratio, positive end-expiratory pressure (PEEP) level, development of bilateral pulmonary infiltrates on chest $\mathrm{x}$-ray, and normal pulmonary capillary wedge pressure (PCWP) within a week of a known clinical insult [7]. The lung injury in ARDS has been reported to undergo three pathophysiological phases: the exudative phase involves damage to the alveolar epithelium leading to increased lung permeability; the proliferative phase involves type II cell proliferation with epithelial cell regeneration, fibroblastic reaction, and remodeling; and the irreversible fibrotic phase, which includes collagen deposition in the lung [8-10]. To understand the development of ARDS, reliable animal models that can mimic these pathophysiological phases are critical. Previous studies have used mouse models for assessment of pulmonary gas exchange and respiratory physiology following controlled induction of ARDS $[11,12]$. However, these mouse models have limitations in the induction of mechanical ventilation and collection of blood samples, and are therefore, not amenable for prolonged study essential to mimic the clinical presentations of ARDS. Large animal models have been reported to show better translational potential in the study of ARDS. Swine models are considered an excellent model for pulmonary pathology due to the similarities with humans in terms of anatomy, genetics and physiology [13]. Various studies have used swine models to study lung development $[14,15]$, acute lung injury (ALI)/ARDS $[16,17]$ and other diseases.

Smoke inhalation is one of the major causes for the development of ARDS after burn injury, with an approximate $30-90 \%$ mortality rate $[18,19]$. Several large animal models are available for smoke/burn injury-induced ARDS [20-22]. However, at present, there is no suitable large animal model available to study isolated smoke inhalation-induced ARDS without confounding variables such as cutaneous burn injury.

The rate of ARDS after smoke inhalation injury varies from patient to patient and is dependent upon several variables such as particulate matter concentration, carbon monoxide concentration, volatile compounds in the smoke, etc. Smoke inhalation injury is the primary injury leading to acute lung injury/ARDS in humans involved in house fires; the presence/absence of cutaneous burn injury plays an additive role in the patient's overall pathophysiology which significantly complicates the medical and surgical management of this patient population. Exposure to indoor air pollution from biomass combustion-as seen during combustion of biomass fuels for cooking and heating used by approximately half of all people in developing countries-is a major source of morbidity and mortality worldwide and continues to be an area of interest for research. As well, the detrimental effect of prolonged exposure to acutely elevated levels of environmental smoke from wildfires or house fires has long-standing interest, especially when studying workplace hazards of firefighters. The main goal of our work presented in the current manuscript was to study isolated smoke inhalation injury without confounding variables such as cutaneous burn, in an attempt to add to current published literature in a way that would be translatable to many real-life situations.

We have developed a large animal, isolated smoke inhalation model to use in our investigations of molecular modification after smoke inhalation and novel therapeutic agents. In the study, pigs were exposed to smoke directly through an endotracheal route to induce lung injury in a controlled environment. Invasive and noninvasive parameters including vital signs, arterial blood gas analysis, and chest $\mathrm{x}$-rays were monitored to pinpoint the development of significant ARDS. IL-6 and histological analysis were performed to understand the pathophysiological profile critical for the development of ARDS in these animals. To our knowledge, this is the first study to develop and detail a large animal model of isolated smoke inhalation-induced ARDS.

\section{Methods \\ Subjects}

All the experiments involving animals were approved by University of Nebraska Lincoln (UNL) Institutional Animal Care and Use Committee (IACUC) (protocol \# 1674). Female pigs $(\sim 50 \mathrm{~kg}, \mathrm{n}=21)$ were housed in pens and cared for according to USDA (United States Department of Agriculture) guidelines. To our knowledge, female pigs do not have higher susceptibility to ARDS compared to male pigs. Our research collaborators had previously developed a porcine model of severe ARDS from intratracheal lipopolysaccharide using female pigs only, and our use of female pigs in the current study was, in part, to assess reliability and reproducibility in their model using a contrasting lung injury.

Animals were acclimated to the facility for 4-7 days and received food reward training to ease handling and blood draws. Six animals died during the experiments due to either anesthesia/surgical complications or smoke inhalation related complication. We continued our next phase of study (involving efficacy of a novel therapeutic for hypoxia) in some of these animals to reduce cost and number of animals used.

\section{Smoke delivery system}

Upon completion of all surgical procedures, animals were exposed to oak wood smoke from a custom-made smoke 
generator connected in parallel to the endotracheal tube. Schematic of the smoke delivery system is shown in Fig. 1.

\section{Surgical procedures}

Sedation for peripheral intravenous catheter (PIV) placement and endotracheal intubation was achieved with a mixture of telazol $(4.4 \mathrm{mg} / \mathrm{kg})$, ketamine $(2.2 \mathrm{mg} / \mathrm{kg})$ and xylazine $(2.2 \mathrm{mg} / \mathrm{kg})$ delivered via intramuscular injection. To assist with intubation, an intravenous bolus dose of fentanyl $(0.05 \mathrm{mg} / \mathrm{kg})$ and/or propofol $(2-4.4 \mathrm{mg} / \mathrm{kg})$ was given as needed. Baseline chest $\mathrm{x}$-rays were obtained (portable x-ray unit EPX-F2800, Ecotron Co. Ltc; wireless digital flat panel detector Mars1417V-TSI, iRay Technology, Shanghai, China) prior to smoke inhalation, and at
24 and $48 \mathrm{~h}$ after smoke inhalation. An endotracheal tube (\#7-8 cuffed; MWI Animal Health, Boise, ID, USA) was inserted into the trachea and animals were ventilated at a tidal volume (TV) of $6 \mathrm{~mL} / \mathrm{kg}$ and PEEP of $5 \mathrm{cmH}_{2} \mathrm{O}$ (Newport HT70, Medtronic, Minneapolis, MN). Respiratory rate (RR) was adjusted to maintain eucapnia as monitored by end-tidal $\mathrm{CO}_{2}\left(\mathrm{ETCO}_{2}\right)$. The fraction of inspired oxygen $\left(\mathrm{FiO}_{2}\right)$ was set at $50 \%$ during surgical procedures (central venous \& arterial catheter placement), then titrated down to $21 \%$ and maintained throughout the experiment. $50 \% \mathrm{FiO}_{2}$ was used to reduce stress to animal during surgical procedures and lasted for 30-40 min. Non-invasive monitoring included blood pressure taken by cuff placed around the animal's hind leg, peripheral oxygen saturation $\left(\mathrm{SpO}_{2}\right)$, heart rate $(\mathrm{HR})$ and $\mathrm{ETCO}_{2}$

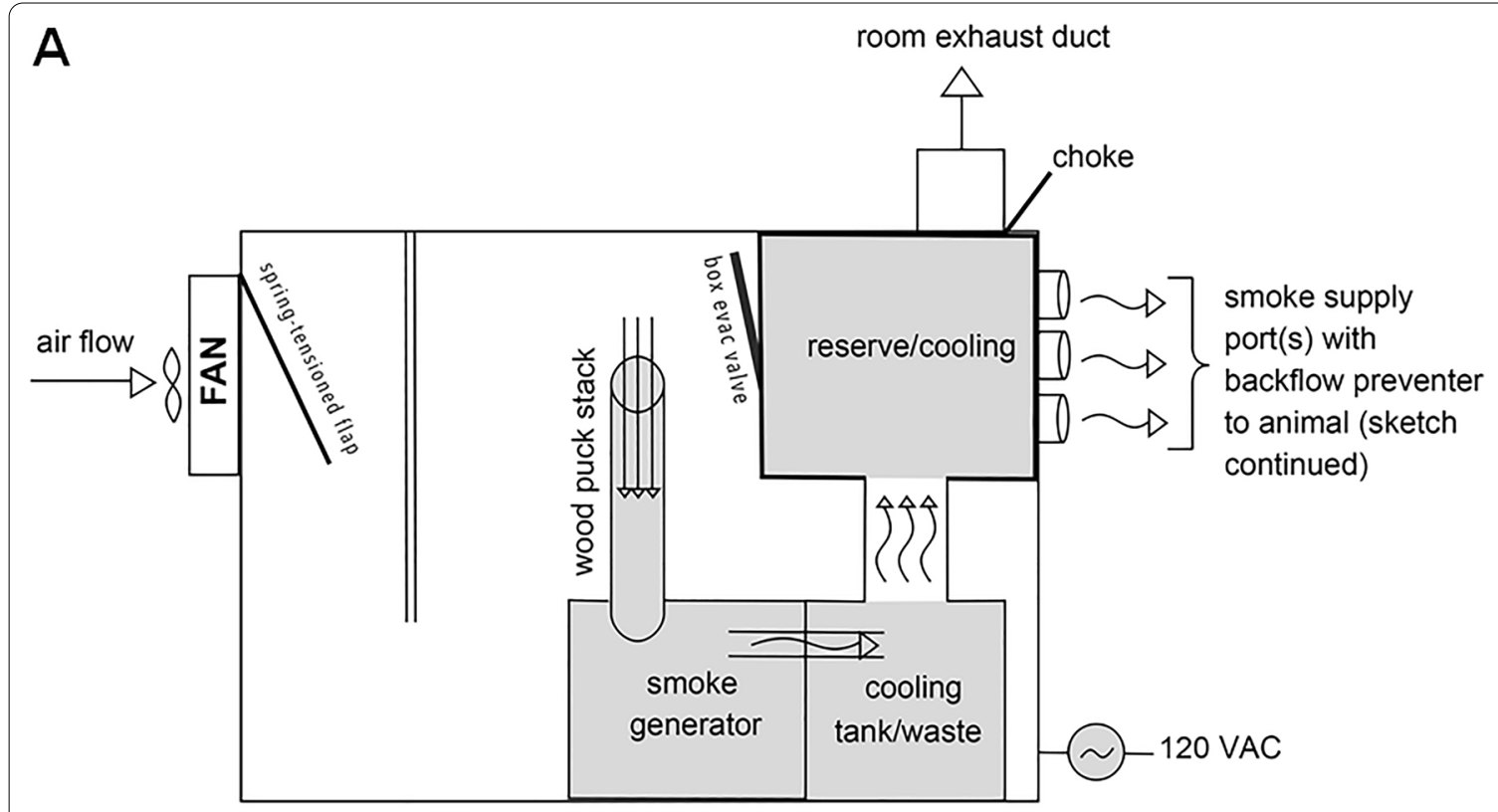

B

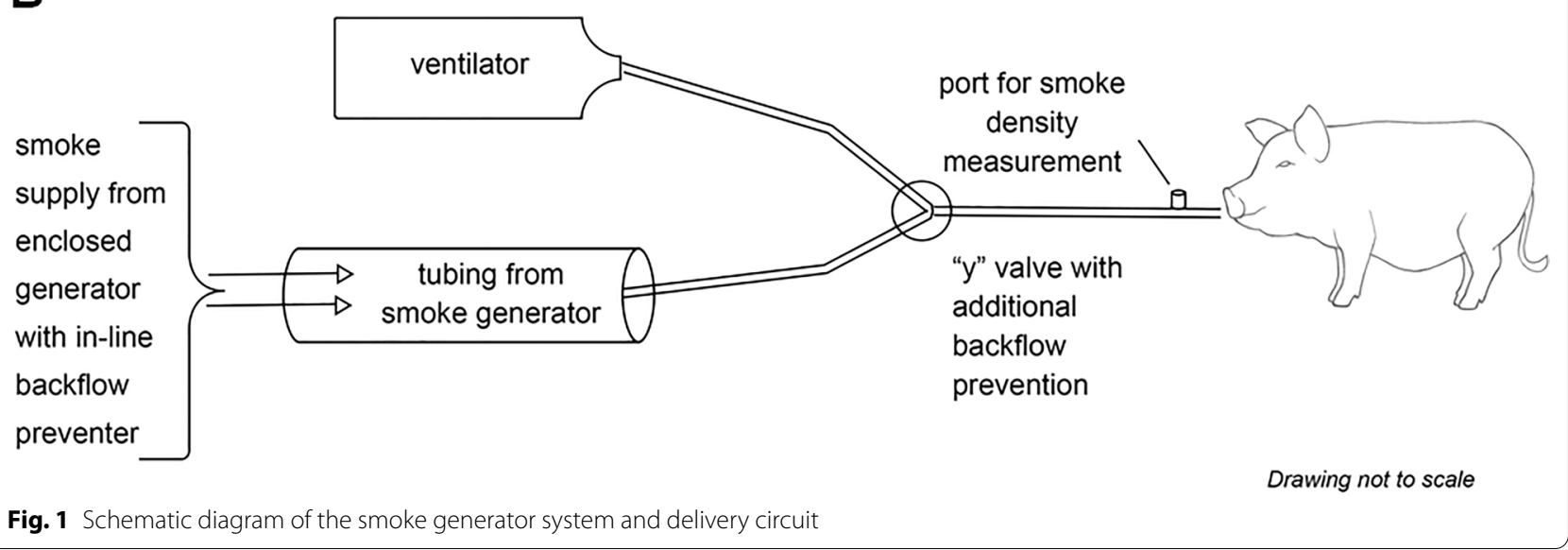


recorded via the Surgivet monitor (Smiths Medical, Dublin, $\mathrm{OH})$. Continuous IV sedation containing midazolam $(0.4-0.7 \mathrm{mg} / \mathrm{kg} / \mathrm{h})$, fentanyl $(0.03-0.1 \mathrm{mg} / \mathrm{kg} / \mathrm{h})$ and propofol $(0.2-0.4 \mathrm{mg} / \mathrm{kg} / \mathrm{min})$ and maintenance IV fluids $(10 \mathrm{~mL} / \mathrm{kg} / \mathrm{h}$ normal saline) were given throughout the procedure via a quadruple-lumen central venous catheter $(8.5 \mathrm{Fr} \times 16 \mathrm{~cm}$, Arrow International $)$ placed in the internal jugular vein. Core temperature was monitored by rectal probe and a circulating warming blanket was used to prevent body cooling. A urinary catheter was placed to monitor output.

Using sterile technique and ultrasound guidance (Butterfly iQ, Butterfly Network, New York City, NY), carotid artery (CA) and femoral artery (FA) access catheters were placed for serial lab draws and invasive blood pressure monitoring (18 GA 16 cm; Femoral Arterial Line Catherization Kit; Teleflex, Morrisville, NC). Pulmonary artery (PA) catheter $(8 \mathrm{~F} \times 110 \mathrm{~cm}$ Swan-Ganz CCOmbo Thermodilution Catheter; Edwards Lifesciences, Irvine, CA) was placed in the internal jugular vein under ultrasound guidance. The CA and PA access ports were connected to Surgivet monitor and Vigilance II monitor, respectively (Edwards Lifesciences, Irvine, CA) with transducers (Meritans DTXPlus, Disposable Pressure Transducer with EasyVent; Merit Medical, South Jordan, UT, USA). Invasive arterial blood pressure, central venous pressure (CVP), pulmonary artery pressure (PAP), cardiac output $(\mathrm{CO})$, mixed venous oxygen saturation $\left(\mathrm{SmvO}_{2}\right)$, and central (core) temperature were monitored throughout the study. Blood samples were drawn from the CA, FA and PA catheters for the measurement of baseline blood gas prior to smoke inhalation and at pre-determined time intervals throughout the study period (ABL80 FLEX CO-OX, Radiometer, Brea, CA). To maintain patency, catheters were flushed throughout the experiment with 3-5 $\mathrm{mL}$ of sterile saline, and a heparin solution (1:500 dilution in 50\% dextrose solution) was infused to fill the volume of the port chosen as a "lock" solution. Sedated/ anesthetized animals from survival surgeries were continuously monitored until sternal recumbence was regained. All catheters were removed after smoke inhalation was completed. The surgical procedures were repeated at $48 \mathrm{~h}$ after smoke inhalation.

\section{Smoke inhalation}

Upon completion of surgical procedures, animals in the SI group were exposed to oak wood smoke from the custom-made smoke chamber (Fig. 1) through the endotracheal tube. The duration of the smoke exposure was 1 to $2 \mathrm{~h}$ starting from $0 \mathrm{~h}$ time point. Smoke was generated at room temperature (74-76 deg F) in a controlled manner. Smoke density/particle load was not measured in the current study. The volume of smoke inhaled was approximately $500 \mathrm{~L}$ per hour. Invasive and noninvasive parameters were monitored continuously during the experiment. Following smoke exposure, blood samples were collected from arterial ports and PAC. Animal was continuously monitored until recovery from general anesthesia. Smoke exposure was stopped immediately if the animal developed hemodynamic instability, which was determined by hypotension (systolic blood pressure less than 60) and irreversible desaturation $\left(\mathrm{SpO}_{2}\right.$ less than $70 \%$ despite rescue maneuvers such as increase in inspired percentage of oxygen).

\section{Ventilator parameters}

On the day of the smoke inhalation, the ventilator parameters were maintained at values: tidal volume, $6 \mathrm{~mL} / \mathrm{kg}=270-360 \mathrm{~L} / \mathrm{min}$; respiratory rate, $18-30 / \mathrm{min}$; PEEP $5 \mathrm{mmHg}$; and $\mathrm{FiO}_{2}, 21-34 \%$ (Table 1). During the $48 \mathrm{~h}$ after smoke inhalation injury, animals were extubated and maintained on room air.

At $48 \mathrm{~h}$ after smoke inhalation injury, animals were again placed on the ventilator, surgical procedures of catheter placement were repeated, serial lab, imaging, and BAL sampling was completed, and animals were humanely euthanized per IACUC protocols. On the final study day, ventilator parameters were similar to the day of smoke inhalation with the exception of maintaining PEEP at 0 . To reduce the effect of elevated mechanical power applied to the lung, resulting in worsening of acute lung injury through development of ventilator-induced lung injury, we elected to avoid this potential confounder by maintaining the PEEP at zero if drive pressure was noted to be adequate and at safe levels. As noted in Swindle's authoritative reference (Swindle MM. Swine in the Laboratory: Surgery, Anesthesia, Imaging, and Experimental Techniques. 2007, Second Edition, CRC Press), swine have very fragile pulmonary tissue that can be damaged by hyperinflation, and it is recommended to maintain pressure between 11-20 cm H20. In our animals, drive pressure was maintained in this range without use of PEEP at $48 \mathrm{~h}$ post smoke inhalation injury.

Table 1 Ventilator parameters

\begin{tabular}{lllll}
\hline Parameters & Baseline & SI $\mathbf{2} \mathbf{h}$ & Post SI $\mathbf{2 4} \mathbf{h}$ & Post $\mathbf{S I} \mathbf{4 8} \mathbf{h}$ \\
\hline $\mathrm{TV}(\mathrm{mL} / \mathrm{kg})$ & $270-360$ & $270-360$ & - & $220-280$ \\
$\mathrm{RR}(\mathrm{bpm})$ & $18-30$ & $18-30$ & - & $16-24$ \\
$\mathrm{FiO}_{2}(\%)$ & $21-34$ & $21-34$ & 21 & 21 \\
$\mathrm{PEEP}\left(\mathrm{cmH}_{2} \mathrm{O}\right)$ & 5 & 5 & - & 0 \\
\hline
\end{tabular}

$\mathrm{SI}$, Smoke inhalation; TV, tidal volume; RR, respiratory rate; bpm, beats per minute; $\mathrm{FiO}_{2}$, fraction of inspired oxygen; PEEP, positive end expiratory pressure $\mathrm{n}=13$ 


\section{Post-surgical animal monitoring and care}

After recovery from surgical anesthesia, all animals were transferred to the post-surgery recovery pen and were monitored $24 \mathrm{~h} /$ day by trained personnel. Chest $\mathrm{x}$-rays were taken and blood samples drawn for ABG analysis at $24 \mathrm{~h}$ and $48 \mathrm{~h}$ following final smoke exposure. Animals $(n=7)$ were humanely euthanized at $48 \mathrm{~h}$ post SI and a full necropsy was performed; the remainder of animals were utilized to continue our lab's therapeutic investigations.

\section{Plasma sample extraction}

Blood samples were collected from the CA catheter at baseline, $2 \mathrm{~h}$, and $48 \mathrm{~h}$ time points in lithium heparin BD Microtainer tubes (Becton, Dickinson and Company, Franklin Lakes, NJ). Tubes were immediately inverted 8-10 times to assure anticoagulation and centrifuged at $4000 \mathrm{~g}$ for $4 \mathrm{~min}$. Supernatants were collected as plasma samples and stored at $-80{ }^{\circ} \mathrm{C}$ until analysis. IL-6 immune assay was performed in samples of 10 animals using IL-6 Quantikine ${ }^{\circledR}$ ELISA kit, catalog No\#P6000B (R\&D Systems, Inc., Minneapolis, MN) on plasma samples following manufacturer's protocol.

\section{Bronchoalveolar lavage (BAL)}

BAL of pig lungs was performed at baseline, $2 \mathrm{~h}$, and $48 \mathrm{~h}$ time points using a bronchoscope in a set of 6 intubated animals. $10 \mathrm{ml}$ of sterile normal saline was instilled to the secondary and tertiary bronchi through the bronchoscope and $\sim 5 \mathrm{ml}$ of the fluid was collected for analysis. BAL fluid samples were centrifuged immediately at $400 \mathrm{~g}$ at $4{ }^{\circ} \mathrm{C}$ for $10 \mathrm{~min}$ and supernatants were at stored at $-80^{\circ} \mathrm{C}$ until analysis. Total protein quantification was performed in samples using Pierce ${ }^{\mathrm{TM}}$ BCA (Bicinchoninic Acid) Protein Assay Kit (Thermo Fisher Scientific Inc. Waltham, MA) following manufacturer's protocol. IL-6 immune assay was performed using IL-6 Quantikine ${ }^{\circledR}$ ELISA (Enzyme-linked immunosorbent assay) kit, cata$\log$ No\#P6000B (R\&D Systems, Inc., Minneapolis, MN) on BAL fluid samples following manufacturer's protocol.

\section{Tissue collection}

Necropsy was performed in 7 animals (control, $n=2$; SI, $\mathrm{n}=5$ ). At necropsy, lung tissues were collected from all five lobes; upper, middle and lower lobes of right lung and upper and lower lobes of left lung for histological examination and pulmonary edema assessment. Tissues for histology were immediately placed in $10 \%$ neutral buffer formalin fixative for approximately $24 \mathrm{~h}$. Formalin fixed tissues were placed into $70 \%$ ethanol and transferred to the University of Nebraska Medical Center (UNMC) Tissue Science Facility (TSF) for further tissue processing and embedment in paraffin blocks.

\section{Lung injury score}

The lung tissue of all five lobes in 10\% neutral formalin was dehydrated in graded concentrations of ethanol solution and cleared in xylene. The tissue samples were then paraffin-embedded, sectioned with 4- $\mu$ m thickness, and stained with hematoxylin and eosin at the UNMC Tissue Sciences Facility using automated Ventana Discovery Ultra (Roche Diagnostics, Indianapolis, IN) as per manufacturer's protocol. For each animal staining was performed in five sections corresponding to the five lobes of lung. An independent pathologist performed a blinded examination of the tissues under light microscope. Ten fields of each lung tissue section were examined at magnification X400. The severity of the lung injury was scored by the criteria of alveolar edema, intraalveolar hemorrhage, and leukocyte infiltration. Alveolar edema and intra-alveolar hemorrhage were scored on a scale from 0 to 3 ; where $0 \leq 5 \%$ of maximum pathology, $1=$ mild $(<10 \%), 2=$ moderate $(10-20 \%)$, and $3=$ severe (20-30\%). Leukocyte infiltration was also scored on a scale from 0 to 3 ; where $0=$ absence of extravascular leukocytes, $1 \leq 10,2=10-45$, and $3 \geq 45$ leukocytes.

\section{Wet-to-dry weight (W/D) ratio}

Lung tissues $(\mathrm{n}=6)$ were dried in an incubator at $60{ }^{\circ} \mathrm{C}$ for 5 days and weighed again (dry weight). The W/D ratio was calculated as the ratio of the wet weight to the final dry weight as described elsewhere [23].

\section{Ki67 immunohistochemistry}

Immunostaining for Ki67 was performed on pig SI and control formalin-fixed, paraffin-embedded lung tissues sections using 1:200 concentration of Ki67 antibody (\#ab16667, Abcam Inc, Cambridge, MA) at UNMC Tissue Sciences Facility using automated Ventana Discovery Ultra (Roche Diagnostics, Indianapolis, IN) in lung tissue samples of 5 animals (control, $n=2$; SI, $n=3$ ) as per manufacturer's protocol. For each animal staining was performed in five tissue sections corresponding to the five lobes of lung. Specimens were processed on the same day to eliminate any variability in conditions. An independent pathologist performed a double-blinded examination of the tissue slides under a light microscope. A total of 2000 cells were counted at magnification of X400 and the percentage of Ki67 positive cells were calculated.

\section{Lung tissue lysate preparation}

Fresh frozen lung lobe tissues with highest injury score $(\mathrm{n}=5)$ were homogenized using $\mathrm{VWR}^{\circledR}$ Mini Bead Mill Homogenizer (VWR International LLC., Radnor, PA) following manufacturer's protocol. Briefly, frozen tissues of two control and three SI animals were washed in cold $\mathrm{X} 1 \mathrm{PBS}$, and $30 \mathrm{mg}$ of each tissue was placed separately 
in a $2 \mathrm{~mL}$ tube containing $2.8 \mathrm{~mm}$ ceramic beads and $750 \mu \mathrm{l}$ of lysis buffer containing RIPA buffer (Thermo Fisher Scientific Inc. Waltham, MA) and protease inhibitor cocktail (Sigma Aldrich Inc., St. Louis, MO) at room temperature. The samples were homogenized at speed 4 for $60 \mathrm{~s}$. This was followed by incubation in ice for $30 \mathrm{~min}$ and centrifugation at $13,000 \mathrm{rpm}$ for $20 \mathrm{~min}$ at $4{ }^{\circ} \mathrm{C}$. Protein concentration was determined using Pierce ${ }^{\mathrm{TM}}$ BCA (Bicinchoninic Acid) Protein Assay Kit (Thermo Fisher Scientific Inc. Waltham, MA) following manufacturer's protocol.

\section{Immunoblot analysis}

Protein $(50 \mu \mathrm{g})$ was separated by SDS- polyacrylamide gel electrophoresis and transferred onto PVDF (polyvinylidene fluoride) membrane (Bio-Rad Lab Inc., Hercules, CA) by electro blotting. The membrane was blocked with $5 \%$ nonfat dry milk in X1 TBST (50 mM Tris, $\mathrm{pH}$ $7.5,150 \mathrm{mM} \mathrm{NaCl}, 0.01 \%$ Tween 20) for $1 \mathrm{~h}$ at room temperature. The membrane was then incubated in primary antibody, IL-6 antibody (\#ab6672, Abcam Inc, Cambridge, MA) or $\beta$-actin (\#4970, Cell Signaling Technology Inc., Danvers, MA) at 1:1000 dilution in X1 TBST with $5 \%$ bovine serum albumin (Sigma Aldrich Inc., St. Louis, $\mathrm{MO}$ ) overnight at $4{ }^{\circ} \mathrm{C}$. The membrane was washed three times with X1 TBST for 10 min each and incubated with HRP-conjugated secondary antibody (\#7074, Cell Signaling Technology Inc., Danvers, MA) at 1:5000 dilution in $\mathrm{X} 1 \mathrm{TBST}$ with $5 \%$ nonfat dry milk for $1 \mathrm{~h}$ at room temperature. Following washes in X1 TBST, proteins were detected using the enhanced chemiluminescence system (Bio-Rad Lab Inc, Hercules, CA).

\section{Statistical analysis}

Statistical analysis was performed using GraphPad prism 8. One-way ANOVA with Tukey's post-hoc analysis and paired $t$ test were utilized to generate adjusted "p" values. $\mathrm{P}$-values $<0.05$ were considered statistically significant.

\section{Results}

The study was divided in two phases. The first phase of the study was performed to determine the optimal duration of smoke exposure required for the development of ARDS. Animals were divided according to smoke inhalation time as shown in the flow diagram in Fig. 2. Smoke inhalation for $1 \mathrm{~h}$ was designated as "SI $1 \mathrm{~h}$ " $(\mathrm{n}=3)$ and smoke inhalation for $2 \mathrm{~h}$ was designated as "SI $2 \mathrm{~h}$ " $(\mathrm{n}=18)$. Fifteen animals successfully completed smoke inhalation (SI) experiment and survived $48 \mathrm{~h}$ post smoke exposure, and six animals died during procedures due to either anesthesia/surgical complications or smoke inhalation-related complication.
Smoke inhalation reduced peripheral oxygenation in large animal model

The $\mathrm{SpO}_{2}$ level was measured continuously on the day of the smoke inhalation experiment and at $24 \mathrm{~h}$ - and $48 \mathrm{~h}$ - post smoke inhalation. The $\mathrm{SpO}_{2}$ level following $1 \mathrm{~h}$ - or $2 \mathrm{~h}$ - smoke inhalation was approximately $95 \%$ and started to decrease at $24 \mathrm{~h}$ post smoke inhalation in both groups. However, $\mathrm{SpO}_{2}$ level significantly dropped in the SI $2 \mathrm{~h}$ group at $48 \mathrm{~h}$ post smoke exposure $(68 \pm 6 \%)$ compared to baseline $(98 \pm 2 \%)$ and the SI $1 \mathrm{~h}$ group $(88 \pm 4 \%)$ (Fig. 3A). The decrease was approximately $30 \%$ as reflected by the delta $\mathrm{SpO}_{2}\left(\Delta \mathrm{SpO}_{2}\right)$ value in SI $2 \mathrm{~h}$ group compared $10 \%$ in the SI $1 \mathrm{~h}$ group (Fig. 3B). In addition, at $48 \mathrm{~h}$ post smoke exposure $\mathrm{PaO}_{2} / \mathrm{FiO}_{2}$ ratio was reduced approximately to 193.4 in the SI $2 \mathrm{~h}$ group compared to baseline and SI $1 \mathrm{~h}$ group values (267-390) (Figs. 3C, D). These results demonstrated that at $48 \mathrm{~h}$ post smoke exposure, animals with smoke inhalation for $2 \mathrm{~h}$ showed sign of respiratory distress as reflected by decrease in $\mathrm{SpO}_{2}$ value below $68 \%$ and indicated that there is injury to the lung.

For the rest of the study, we concentrated at the $2 \mathrm{~h}$ time point for duration of smoke exposure, and repeated experiments to ensure reproducibility of this model. Animals were exposed to smoke for $2 \mathrm{~h}$ duration and designated as "SI" animals. Consistent with the result in Fig. 3, we observed a $22-40 \%$ decrease in $\mathrm{SpO}_{2}$ compared to baseline values (Figs. $4 \mathrm{~A}, \mathrm{~B}, \mathrm{p}<0.0001$ ). In addition, arterial and mixed venous oxygen saturation $\left(\mathrm{SaO}_{2}\right.$ and $\mathrm{SmvO}_{2}$ ) were reduced by approximately $39-43 \%$ compared to the corresponding baseline values (Figs. 4C, D, $\mathrm{p}<0.0001$ ).

All results presented to follow are after $2 \mathrm{~h}$ smoke exposure.

\section{Smoke inhalation induced hypoxemia in large animal model}

Arterial blood gas (ABG) was measured from both arterial and mixed venous blood samples throughout the study. The arterial partial pressure of oxygen $\left(\mathrm{PaO}_{2}\right)$ level started to decrease $1 \mathrm{~h}$ after smoke exposure and dropped significantly at $48 \mathrm{~h}$ post smoke exposure to $43 \mathrm{mmHg}$ from baseline value of $95 \mathrm{mmHg}$ (Fig. 5A). Delta $\mathrm{PaO}_{2}\left(\Delta \mathrm{PaO}_{2}\right)$ value in Fig. $5 \mathrm{~B}$ showed a difference of $53 \pm 5.8 \mathrm{mmHg}(\mathrm{p}<0.0001)$. As expected, there was a rise in partial pressure of carbon dioxide $\left(\mathrm{PaCO}_{2}\right)$ level (Fig. 5A) with an increase in $\triangle \mathrm{PaCO}_{2}$ value by $27.5 \pm 2.34 \mathrm{mmHg}$ compared to the baseline value (Fig. 5B, p<0.0001). In correlation with findings from arterial samples, at $48 \mathrm{~h}$ post smoke exposure we observed significant reduction in the partial pressure of mixed venous oxygen $\left(\Delta \mathrm{PmvO}_{2}\right)$ level 


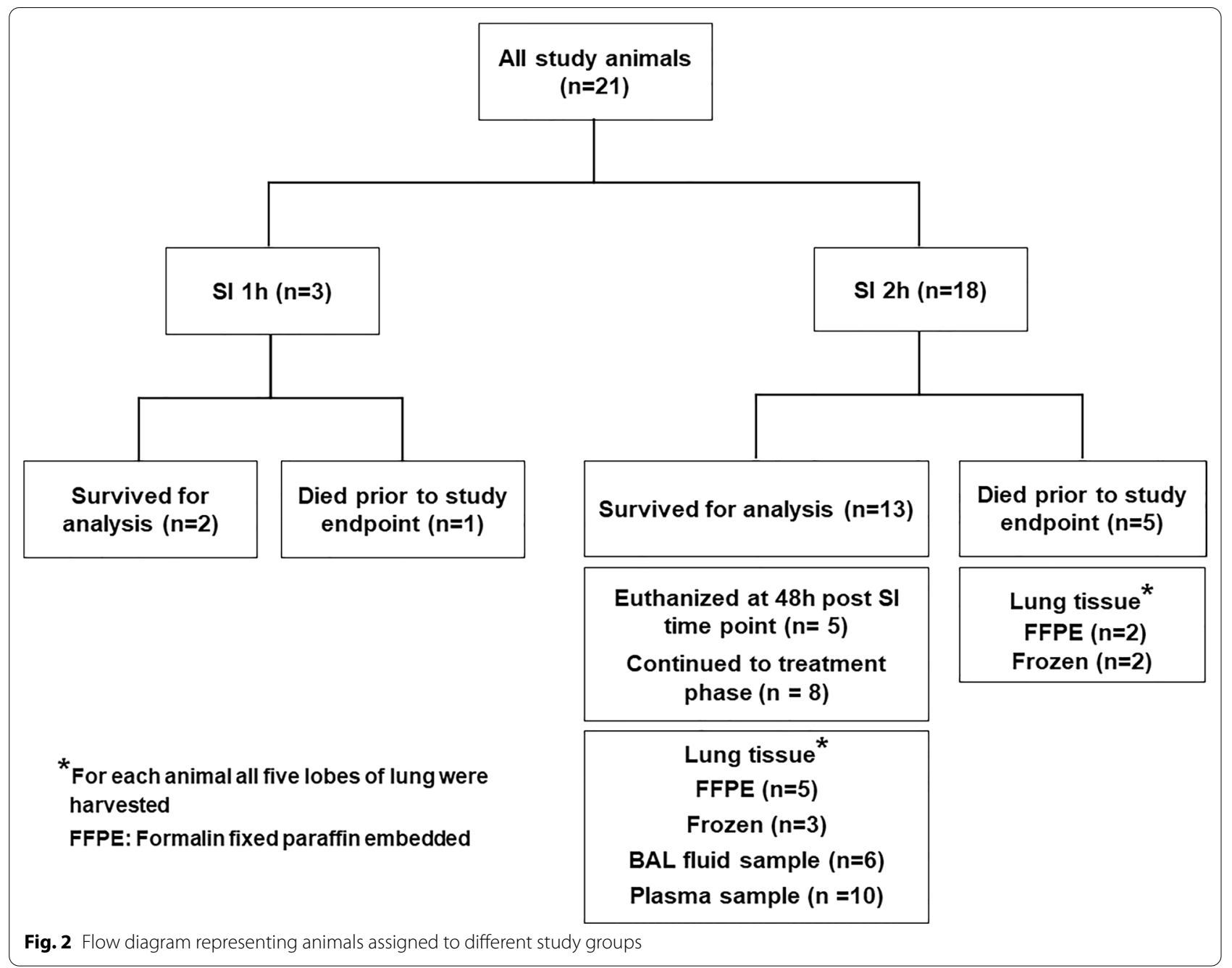

$(15.12 \pm 2.12 \mathrm{mmHg})$ and corresponding increase in partial pressure of mixed venous carbon dioxide $\left(\triangle \mathrm{PmvCO}_{2}\right)$ level $(19.23 \pm 4.01 \mathrm{mmHg})$ compared to the baseline values (Figs. $5 \mathrm{C}, \mathrm{D}, \mathrm{p}<0.0001$ to $=0.0005$ ). The $\mathrm{pH}$ level was also significantly decreased at $48 \mathrm{~h}$ post smoke inhalation (Table $2, \mathrm{p}<0.001$ ) with no significant change in the $\mathrm{HCO}_{3}$ levels (Table 2). Consistent with the rise in $\mathrm{PaCO}_{2}$ value post smoke inhalation, end tidal $\mathrm{CO}_{2}\left(\mathrm{ETCO}_{2}\right)$ - which measures the concentration of $\mathrm{CO}_{2}$ exhaled at the endotracheal tube-significantly increased from the baseline value of $33.9 \pm 12.8 \mathrm{mmHg}$ to $52.63 \pm 13.5 \mathrm{mmHg}$ at $48 \mathrm{~h}$ post smoke inhalation (Table 2, $\mathrm{p}=0.009$ ).

Previous studies have documented $\mathrm{PaO}_{2} / \mathrm{FiO}_{2}$ ratio to assess the level of hypoxemia in the animal model $[17,24]$. We also demonstrated significant reduction in $\mathrm{PaO}_{2} / \mathrm{FiO}_{2}$ ratio at $48 \mathrm{~h}$ post smoke exposure $(198.87 \pm 37.13)$, with $40 \%$ of animals having values less than 170 (Fig. 6A). The difference in the $\Delta \mathrm{PaO}_{2} /$ $\mathrm{FiO}_{2}$ value between the baseline and at $48 \mathrm{~h}$ post smoke exposure was approximately 208 (Fig. 6B, p <0.0001). Furthermore, hematocrit (Hct), hemoglobin $(\mathrm{Hb})$, and fractional oxyhemoglobin $\left(\mathrm{FO}_{2} \mathrm{Hb}\right)$ values were reduced $48 \mathrm{~h}$ after smoke inhalation compared to baseline (Table 2, $\mathrm{p}<0.001$ to $=0.02$ ). As expected, total arterial oxygen content $\left(\mathrm{CaO}_{2}\right)$ and mixed venous oxygen content $\left(\mathrm{CmvO}_{2}\right)$ of blood were also significantly reduced $48 \mathrm{~h}$ after smoke inhalation compared to the corresponding baseline values (Figs. 6C, D, $\mathrm{p}<0.0001$ ). There were no significant changes in heart rate (HR), temperature (Temp), mean arterial pressure (MAP) and pulmonary arterial pressure (PAP) (Table 2).

\section{Effect of smoke inhalation on lung parenchyma}

Smoke inhalation has been reported to increase capillary leakage $[25,26]$. Consistent with previous studies, we observed diffuse, bilateral infiltrates on repeated 

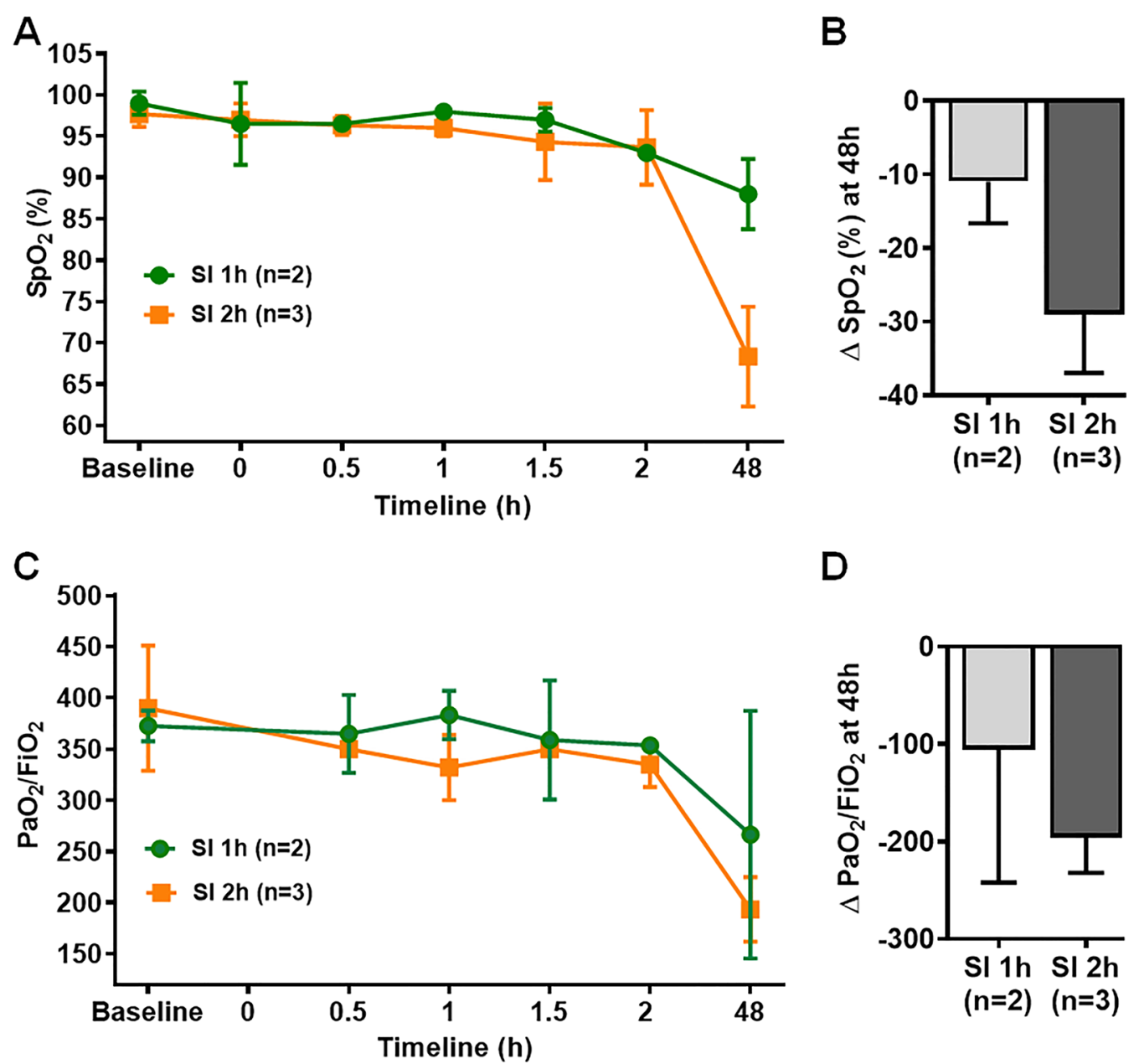

Fig. 3 Effect of smoke duration in large animal. A, B Peripheral oxygen saturation $\left(\mathrm{SpO}_{2}\right)$ level was measured in $1 \mathrm{~h}$ - and 2 h-smoke inhalation

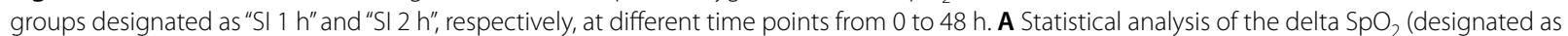
$\triangle \mathrm{SpO}_{2}$ ) between $\mathrm{SI} 1 \mathrm{~h}$ and $\mathrm{SI} 2 \mathrm{~h}$ groups $(\mathbf{B}) . \Delta \mathrm{SpO}_{2}$ for each group represented the difference in $\mathrm{SpO}_{2}$ level between baseline and $48 \mathrm{~h}$ post smoke exposure. $\mathbf{C}$, D The ratio of partial pressure of arterial oxygen $\left(\mathrm{PaO}_{2}\right)$ and fraction of inspired oxygen $\left(\mathrm{FiO}_{2}\right)$, designated as " $\mathrm{PaO}_{2} / \mathrm{FiO}_{2}$ " was measured in $\mathrm{SI} 1 \mathrm{~h}$ and $\mathrm{SI} 2 \mathrm{~h}$ group of animals (C). Statistical analysis of the delta $\mathrm{PaO}_{2} / \mathrm{FiO}_{2}$ (designated as $\triangle \mathrm{PaO}_{2} / \mathrm{FiO}_{2}$ ) between $\mathrm{SI} 1 \mathrm{~h}$ and $\mathrm{SI} 2 \mathrm{~h}$ groups (D). $\triangle \mathrm{PaO}_{2} / \mathrm{FiO}_{2}$ for each group represented the difference in $\mathrm{PaO}_{2} / \mathrm{FiO}_{2}$ level between baseline and $48 \mathrm{~h}$ post smoke exposure. Smoke inhalation started at $0 \mathrm{~h}$ time point $\mathrm{A} p$ value of $<0.05$ was considered statistically significant

radiographic assessment of lung injury with chest $\mathrm{x}$-rays in both ventral-dorsal and lateral views at $48 \mathrm{~h}$ after smoke injury (Fig. 7A). In contrast, both lungs were normal in the chest $\mathrm{x}$-rays taken before smoke inhalation (Fig. 7A). Histologic examination of lung tissue $48 \mathrm{~h}$ post smoke exposure showed an increase in the number of leukocyte infiltration, intra-alveolar hemorrhage, and alveolar edema compared to the control animal group (Figs. 7B, C); and the overall lung injury score was significantly increased (Fig. 7D; $\mathrm{p}=0.0376$ ). We also observed an increase in the average wet-dry weight (W/D) ratio of lung tissues $48 \mathrm{~h}$ after smoke exposure $(6.233 \pm 1.14)$ compared to the control animals $(5.445 \pm 0.36)$ (Fig. 7E, $\mathrm{p}=0.0091)$. Ki67 immunohistochemistry was performed in paraffin embedded lung tissue sections of two control and two smoke inhalation animals. Lung tissue sections of animals at $48 \mathrm{~h}$ post smoke inhalation showed a statistically significant decrease in the number of proliferative cells compared to the control animals (Fig. 7F, $\mathrm{p}=0.0292$ ). Furthermore, BAL fluid samples taken from six animals showed significant increase in the total protein concentration of BAL fluid $48 \mathrm{~h}$ post smoke inhalation compared to the baseline (Fig. 7G, $\mathrm{p}=0.0436$ ).

\section{Effect of smoke inhalation on IL- 6 expression level}

We observed a significant increase in IL-6 level in BAL fluid samples at $48 \mathrm{~h}$ post smoke exposure (Fig. 8A, $\mathrm{p}=0.0102$ ), and a marginal increase at $2 \mathrm{~h}$ time point 

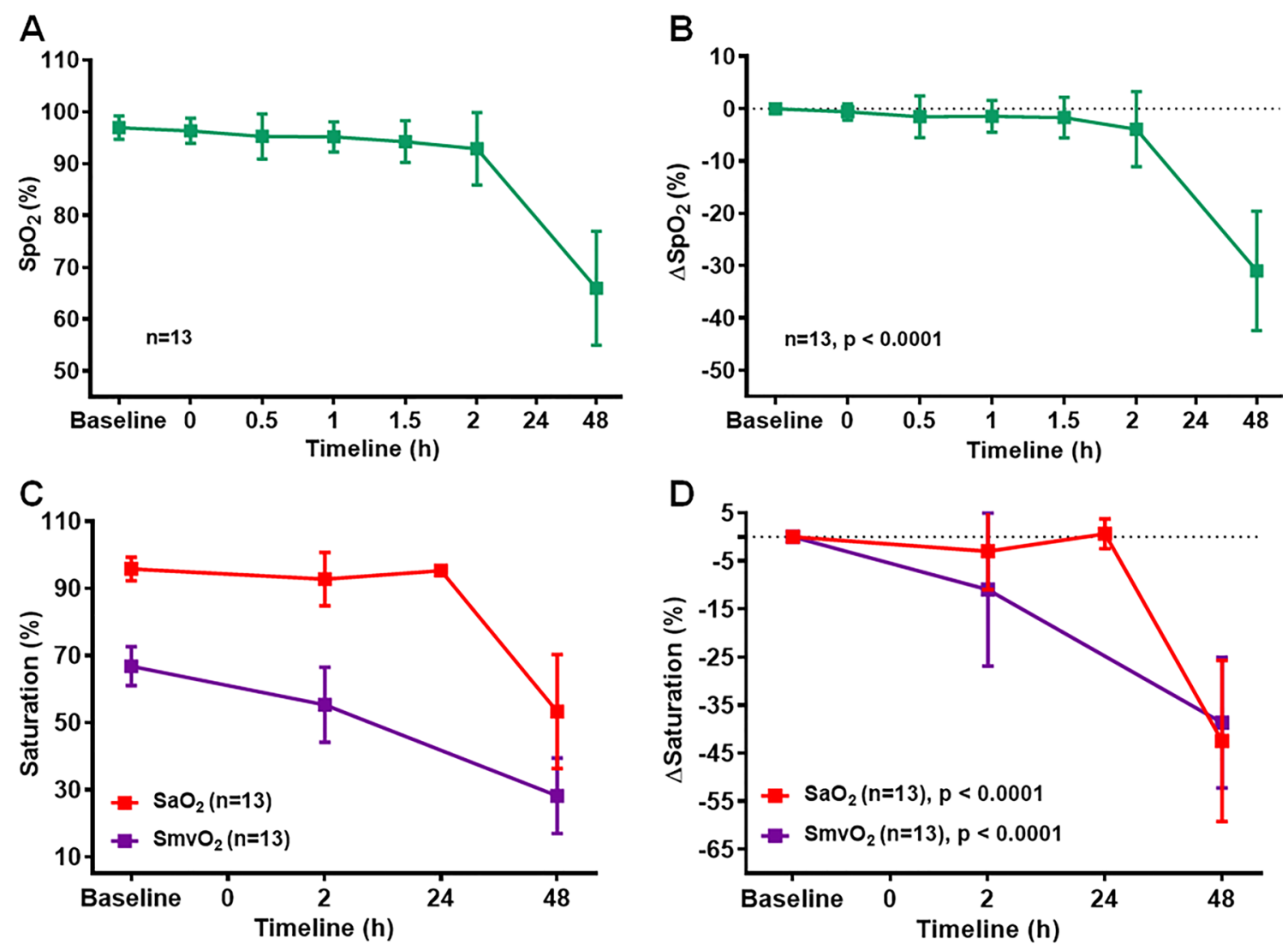

Fig. 4 Smoke inhalation reduced oxygen saturation in large animals. A, B Peripheral oxygen saturation $\left(\mathrm{SpO}_{2}\right)$ level was measured in a different set of $2 \mathrm{~h}$ smoke inhalation group designated as "SI" at different time points from 0 to $48 \mathrm{~h}$. $\mathbf{A} \Delta \mathrm{SpO}_{2}$ values between baseline and different time points (B). C, D Arterial oxygen saturation $\left(\mathrm{SaO}_{2}\right)$ and mixed venous oxygen saturation $\left(\mathrm{SmvO}_{2}\right)$ levels were measured in $\mathrm{Sl}$ group at baseline, $2 \mathrm{~h}$, $24 \mathrm{~h}$, and $48 \mathrm{~h}$ time points $(\mathbf{C})$. Delta $\mathrm{SaO}_{2}\left(\Delta \mathrm{SaO}_{2}\right)$ and delta $\mathrm{SmvO}_{2}\left(\Delta \mathrm{SmvO}_{2}\right)$ values were calculated between baseline and different time points (D). Delta value for each parameter represented the difference with corresponding baseline values. $\mathrm{SaO}_{2}$ level was measured at $24 \mathrm{~h}$ for $\mathrm{n}=8, \mathrm{SpO} \mathrm{O}_{2}$ and $\mathrm{SmvO}_{2}$ levels were not measured at $24 \mathrm{~h}$ time point. Smoke inhalation started at $0 \mathrm{~h}$ time point. A p value of $<0.05$ was considered statistically significant

(Fig. $8 \mathrm{~A}, \mathrm{p}=0.1010$ ) compared to the baseline level. IL-6 immune assay analysis in plasma samples of 10 animals also demonstrated a significant increase in IL-6 level in SI animals at $2 \mathrm{~h}$ smoke inhalation compared to the baseline (Fig. $8 \mathrm{~B}, \mathrm{p}=0.0046$ ). However, no significant increase was observed in animals at $48 \mathrm{~h}$ post smoke inhalation (Fig. 8B, p=0.1934). Increased IL-6 expression level obtained in BAL fluid and plasma sample immunoassay analyses were further validated by the robust upregulation of IL-6 expression level in immunoblotting of lung tissue lysates at $48 \mathrm{~h}$ post smoke inhalation in SI animals compared to the control animals (Fig. 8C).

\section{Discussion}

ARDS arises from diverse insults in the lungs, and a variety of lung injury animal models have been developed to study the pathophysiological processes [3, 27]. Frequently used models for ALI includes intravenous infusion of oleic acid [28, 29], repeated bronchoalveolar lavage with saline [30, 31], and intravenous infusion of endotoxin [32, 33]. These models studied acute lung injury manifested within $24 \mathrm{~h}$. In the current model, we wished to focus on the acute phase of injury after smoke inhalation; extrapolating from our experience with human smoke inhalation, the effects of smoke injury typically peak at $48-72 \mathrm{~h}$ post-exposure. We did not desire to confound the current study with sub-acute or chronic effects of ARDS. As such, ours is an acute model and does not reflect the long-term effects of ARDS, i.e. tissue remodeling and fibrosis.

Furthermore, no large animal models of ARDS from isolated smoke inhalation injury exists in the literature. Our main goal was to contribute to the scientific community by developing such a model that is reliable and reproducible. Smoke inhalation is a major predisposing factor for the development of ARDS and is considered 

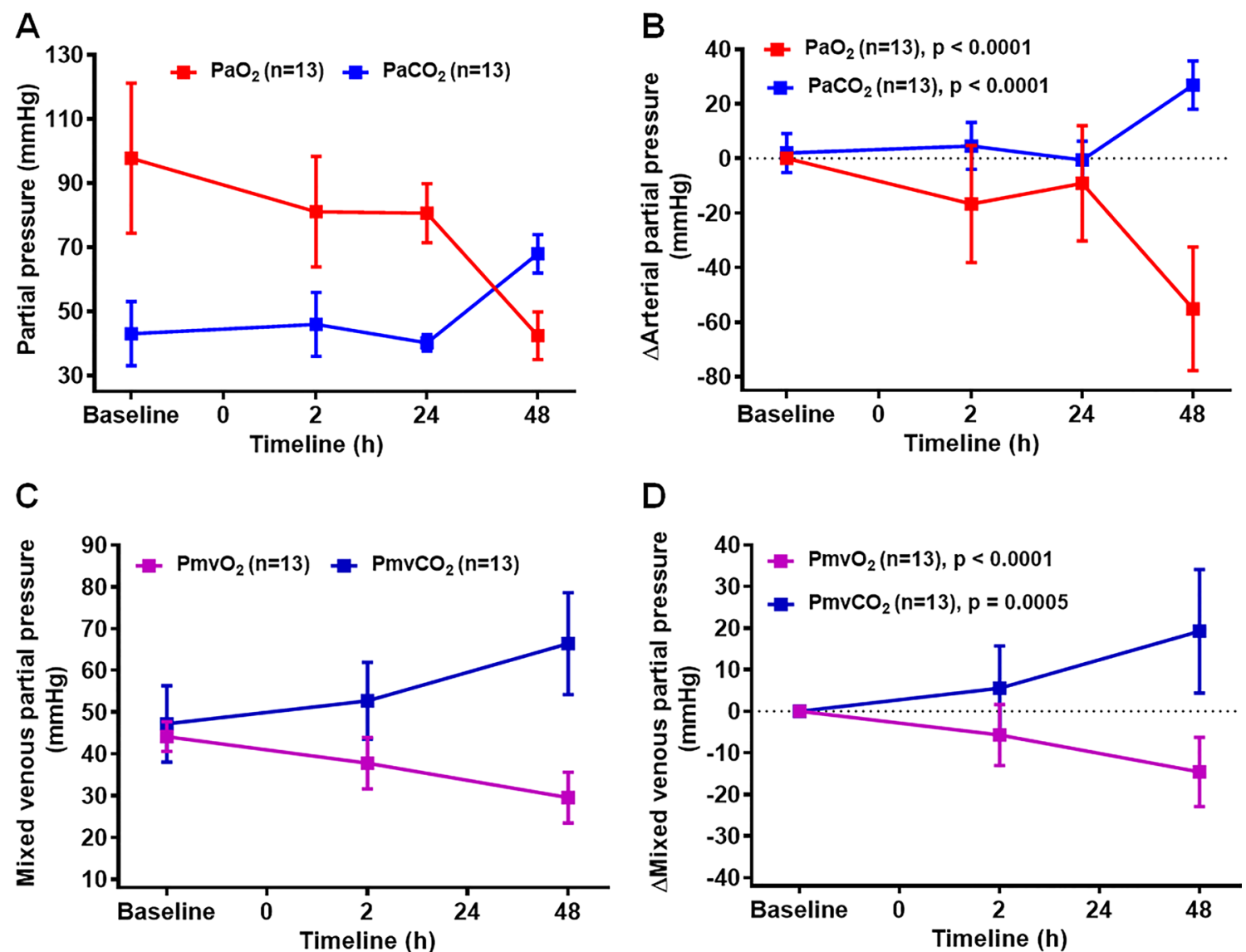

Fig. 5 Smoke inhalation reduces $\mathrm{PO}_{2}$ with reciprocal increase in $\mathrm{PCO}_{2}$ Arterial partial pressure of oxygen $\left(\mathrm{PaO}_{2}\right)$ and carbon-dioxide $\left.(\mathrm{PaCO})_{2}\right)$ levels were measured in SI group at baseline, $2 \mathrm{~h}, 24 \mathrm{~h}$, and $48 \mathrm{~h}$ time points $(\mathbf{A})$. Delta $\mathrm{PaO}_{2}\left(\triangle \mathrm{PaO}_{2}\right)$ and delta $\mathrm{PaCO}_{2}\left(\triangle \mathrm{PaCO}_{2}\right)$ values between baseline and different time points (B). Mixed venous partial pressure of pressure of oxygen $\left(\mathrm{PmvO}_{2}\right)$ and carbon dioxide $\left(\mathrm{Pmv}_{\mathrm{CO}}\right)$ level were measured in $\mathrm{SI}$ group at baseline, $2 \mathrm{~h}, 24 \mathrm{~h}$, and $48 \mathrm{~h}$ time points $(\mathbf{C})$. Delta $\mathrm{PmvO}_{2}\left(\triangle \mathrm{PmvO}_{2}\right)$ and delta $\mathrm{PmvCO}_{2}\left(\triangle \mathrm{PmvCO}_{2}\right)$ values were calculated between baseline and different time points $(\mathbf{D})$. Delta value for each parameter represented the difference with corresponding baseline values. $\mathrm{PaO}_{2}$ and $\mathrm{PaCO}_{2}$ levels were measured at $24 \mathrm{~h}$ for $\mathrm{n}=8 ; \mathrm{PmvO}_{2}$ and $\mathrm{PmvCO}_{2}$ levels were not measured at $24 \mathrm{~h}$ time line. Smoke inhalation started at $0 \mathrm{~h}$ time point. A p value of $<0.05$ was considered statistically significant

Table 2 Hemodynamic parameters

\begin{tabular}{lcccc}
\hline Parameters & Baseline & SI $\mathbf{h}$ & Post SI $\mathbf{2 4} \mathbf{h}^{\mathbf{a}}$ & Post SI $\mathbf{4 8} \mathbf{h}$ \\
\hline Art pH & $7.47 \pm 0.07$ & $7.45 \pm 0.07$ & $7.47 \pm 0.04$ & $7.30 \pm 0.10^{* * *}$ \\
$\mathrm{Art} \mathrm{HCO}_{3}(\mathrm{mmol} / \mathrm{L})$ & $29.33 \pm 2.19$ & $30.42 \pm 1.80$ & $27.49 \pm 3.02$ & $30.09 \pm 3.70$ \\
$\mathrm{ETCO}_{2}(\mathrm{mmHg})$ & $33.90 \pm 12.8$ & $40.56 \pm 11.8$ & - & $52.63 \pm 13.5^{* *}$ \\
$\mathrm{Hct}(\%)$ & $34.35 \pm 2.82$ & $34.02 \pm 3.46$ & $31.75 \pm 2.99$ & $29.58 \pm 6.04^{*}$ \\
$\mathrm{Hb}(\mathrm{g} / \mathrm{dl})$ & $11.08 \pm 0.84$ & $11.04 \pm 1.15$ & $10.37 \pm 0.94$ & $9.50 \pm 1.89^{*}$ \\
$\mathrm{FO}{ }_{2} \mathrm{Hb}(\%)$ & $95.35 \pm 3.80$ & $91.74 \pm 7.89$ & - & $52.13 \pm 16.4^{* * *}$ \\
$\mathrm{HR}(\mathrm{bpm})$ & $87.17 \pm 18.3$ & $92.91 \pm 41.63$ & - & $88.75 \pm 12.88$ \\
$\mathrm{Temp}\left({ }^{\circ} \mathrm{C}\right)$ & $37.18 \pm 0.87$ & $36.67 \pm 4.43$ & - & $41.27 \pm 11.1$ \\
$\mathrm{MAP}(\mathrm{mmHg})$ & $66.50 \pm 26.8$ & $72.68 \pm 12.8$ & - & $74.83 \pm 19.0$ \\
PAP $(\mathrm{mmHg})$ & $15.25 \pm 9.20$ & $14.71 \pm 10.2$ & - & $23.84 \pm 17.2$ \\
\hline
\end{tabular}

Values are calculated as mean $\pm \mathrm{SD}, \mathrm{n}=13$. $\mathrm{Art} \mathrm{pH}$, arterial $\mathrm{pH} ; \mathrm{Art}_{\mathrm{HCO}}$, arterial bicarbonate; $\mathrm{ETCO}_{2}$, end tidal carbon dioxide; $\mathrm{Hct}$, hematocrit; $\mathrm{Hb}$, hemoglobin; $\mathrm{FO}_{2} \mathrm{Hb}$, fractional oxyhemoglobin MAP, mean arterial pressure; $\mathrm{PAP}$, pulmonary arterial pressure; $\mathrm{HR}$, heart rate; Temp, temperature

** $p<0.01, * * * p<0.001, * * * * p<0.0001$

${ }^{\mathrm{a}} \mathrm{n}=8$ 

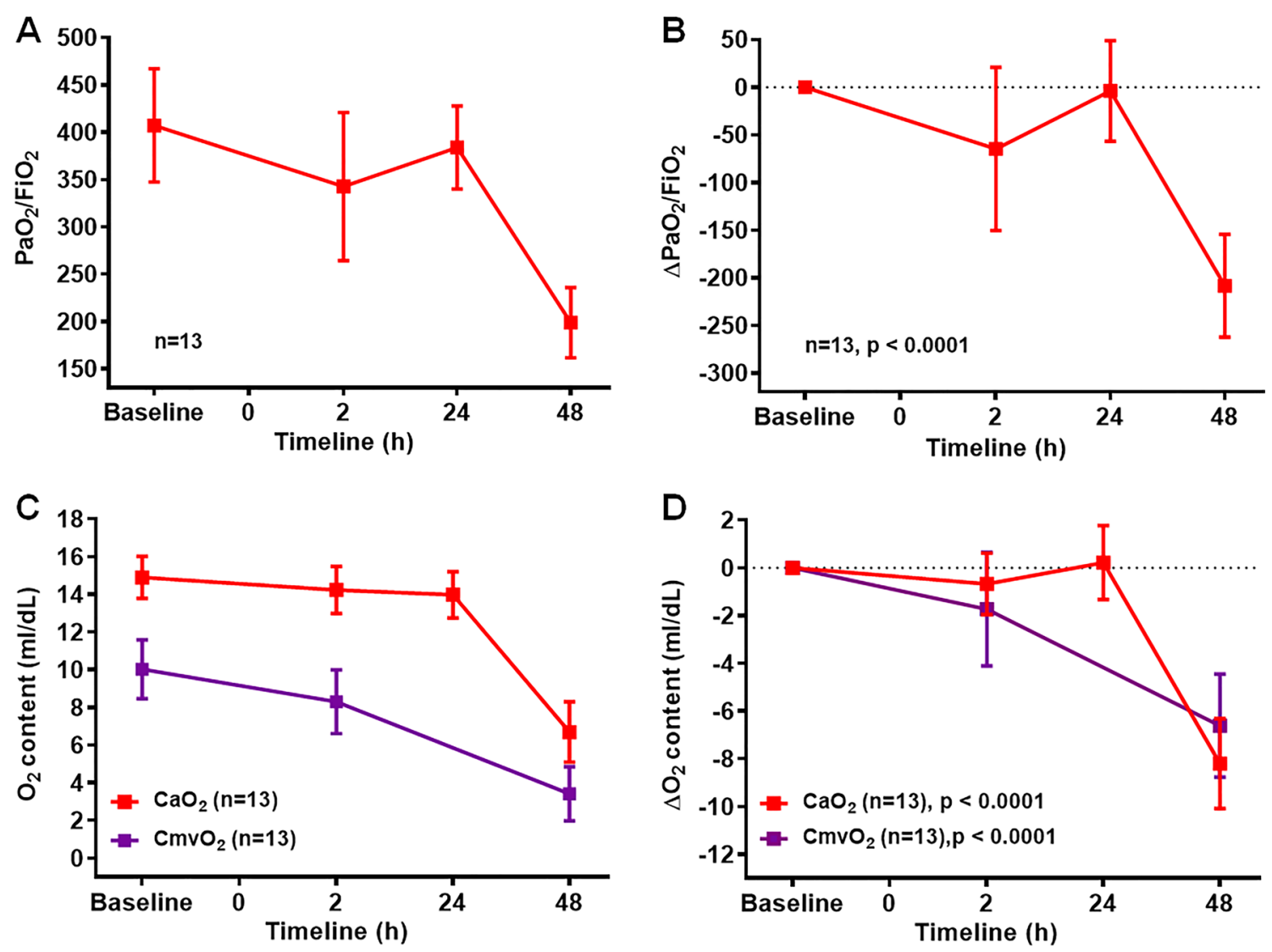

Fig. $6 \mathrm{PaO}_{2} / \mathrm{FiO}_{2}$ and total oxygen content reduced in smoke inhalation induced lung injury. A The ratio of $\mathrm{PaO}_{2}$ and $\mathrm{FiO}_{2}$, designated as " $\mathrm{PaO} / 2 / \mathrm{FiO}_{2}$ " was measured in $\mathrm{SI}$ group of animals at baseline, $2 \mathrm{~h}, 24 \mathrm{~h}$, and $48 \mathrm{~h}$ time points. B Delta $\mathrm{PaO}_{2} / \mathrm{FiO}_{2}\left(\triangle \mathrm{PaO}_{2} / \mathrm{FiO}_{2}\right)$ values were calculated between baseline and different time points. C Total arterial oxygen content $\left(\mathrm{CaO}_{2}\right)$ and total mixed venous oxygen content $\left(\mathrm{CmvO}_{2}\right)$ levels were measured in $\mathrm{Sl}$ group at baseline, $2 \mathrm{~h}, 24 \mathrm{~h}$ and $48 \mathrm{~h}$ time points. D Delta $\mathrm{CaO}_{2}\left(\Delta \mathrm{CaO}_{2}\right)$ and delta $\mathrm{CmvO}_{2}\left(\Delta \mathrm{CmvO}_{2}\right)$ values were calculated between baseline and different time points (D). Delta value for each parameter represented the difference with the corresponding baseline values. $\mathrm{PaO}_{2} / \mathrm{FiO}_{2}$ and $\mathrm{CaO} 2$ and levels were measured at $24 \mathrm{~h}$ for $\mathrm{n}=8$ and $\mathrm{n}=6$ respectively; $\mathrm{CmvO}_{2}$ level was not measured at $24 \mathrm{~h}$ time line. Smoke inhalation started at $0 \mathrm{~h}$ time point. A p value of $<0.05$ was considered statistically significant

together with burn injury in several animal models for smoke/burn injury-induced ARDS [17, 20-22]. However, there is no suitable large animal model available for isolated smoke inhalation-induced ARDS that replicates human ARDS without confounding variables such as cutaneous burn injury.

The present study utilized oak wood to generate smoke from the smoke generator. Oak wood is easily available and its composition and particle size has been well -characterized [34, 35]. Additionally, commercially-available oak are compatible with the smoke generator system used in the study. Oak wood is mainly composed of cellulose (41-46\%), hemicellulose (19$22 \%$ ) and lignin (29-30\%), together with resins and variable amounts of water and inorganic matter [34]. Oak wood generates $\sim 2 \mathrm{~g}$ fine particulate per $\mathrm{kg}$ of wood burned which composed primarily of organic carbon $(\sim 50 \%)$ and elemental carbon $(\sim 3 \%)$, and also include ions and elements [35]. Some of the organic compounds found in fine particle mass are levoglucosan and other sugar derivatives, substituted syringols, guaiacol and substituted guaiacol, substituted benzene and phenols, PAH and alkyl-PAH and phytosteroids [35]. We reported the development and validation of a large animal model for isolated smoke inhalation-induced ARDS. Following smoke exposure through an endotracheal tube, animal reproduced the entire set of clinical parameters for defining ARDS, such as significant decrease in $\mathrm{SpO}_{2}$ to approximately 65\%, mean $\mathrm{PaO}_{2} /$ $\mathrm{FiO}_{2}$ value of 196, diffuse bilateral pulmonary infiltrates on chest X-rays at $48 \mathrm{~h}$ post smoke inhalation, and no clinical evidence of cardiac failure or fluid overload as explained by ARDS Definition Task Force, 2012 [7]. We also documented significant decreases in $\mathrm{PaO}_{2}$ and the reciprocal increase in $\mathrm{PaCO}_{2}$. Studies have shown that increase in $\mathrm{PaCO}_{2}$ and $\mathrm{ETCO}_{2}$ levels correlate with the 

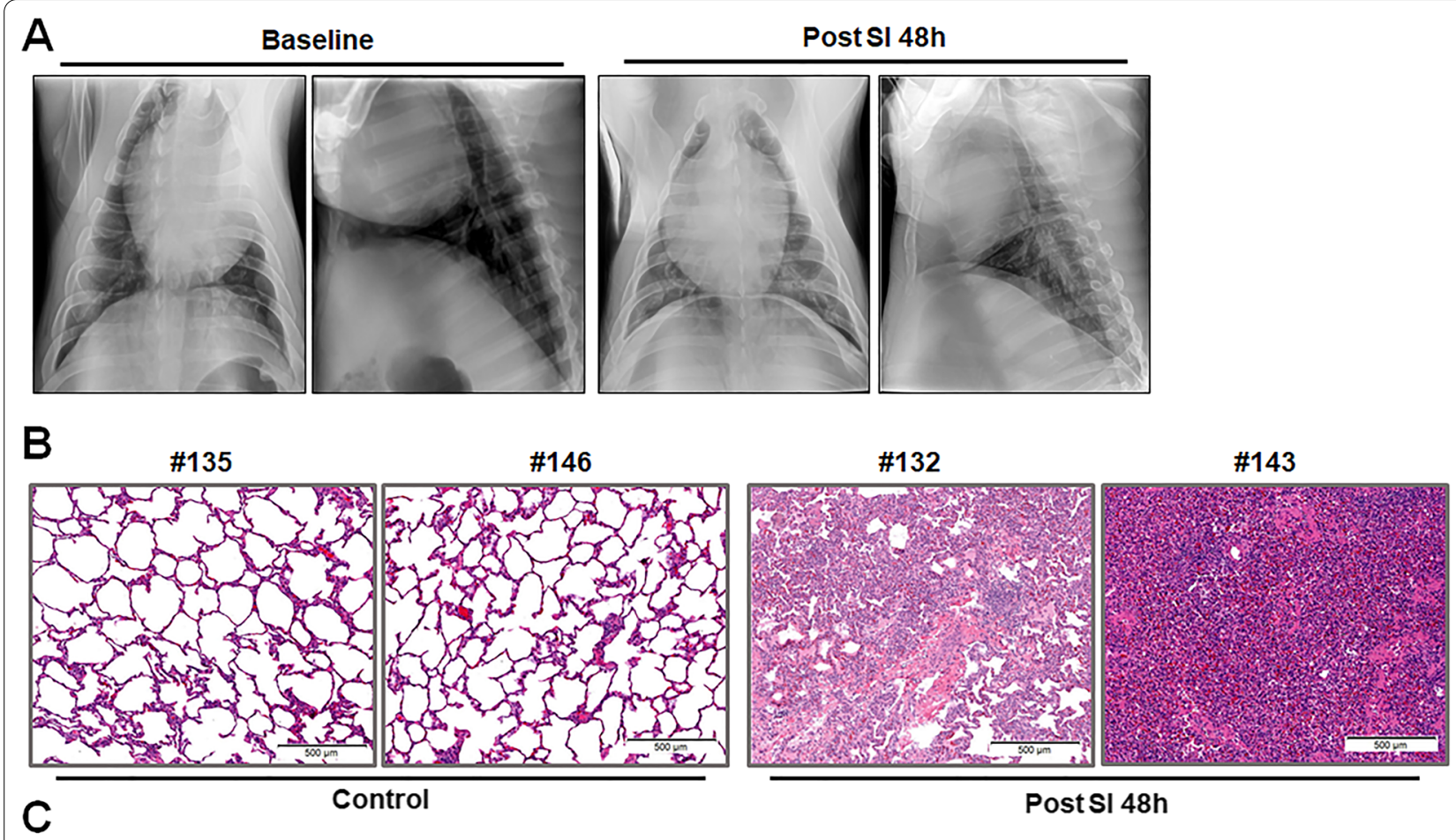

\section{Lung injury score}

\begin{tabular}{lccc}
\hline Parameters & Leucocyte infiltration & Intra-alveolar hemorrhage & Alveolar edema \\
\hline Control $(n=2)$ & $1.77 \pm 0.5$ & 0 & 0 \\
Post SI 48h $(n=5)$ & $2.43 \pm 0.3$ & $0.62 \pm 0.58$ & $0.15 \pm 0.19$ \\
\hline
\end{tabular}
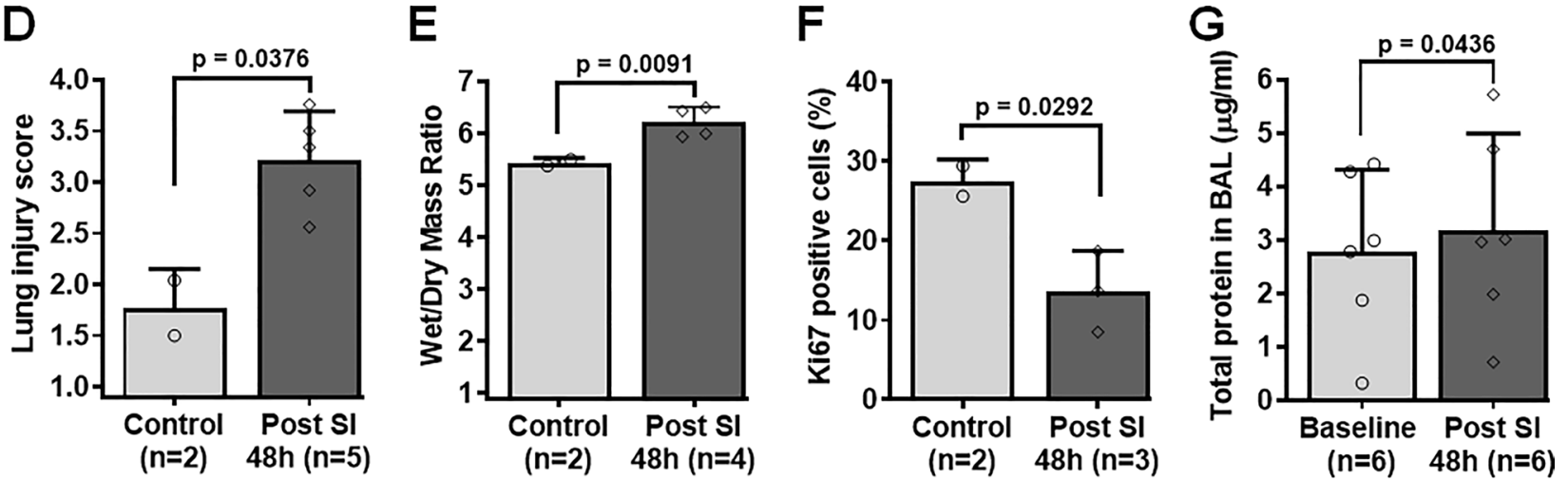

Fig. 7 Effect of smoke inhalation in lung parenchyma. A Ventral-dorsal and lateral view chest x-rays at baseline and $48 \mathrm{~h}$ after smoke inhalation. Hematoxylin and eosin (H\&E) staining on two sets of paraffin embedded lung tissue sections of control and SI animals (B). Statistical analysis of lung injury score between control and SI animals (C, D). E Statistical analysis of wet/dry weight (W/D) ratio between control and SI animals. F Percentage of Ki67 positive cells on the paraffin embedded lung tissue sections of control and SI animals. G Quantification of total protein concentration of BAL fluid samples in SI group at baseline and $48 \mathrm{~h}$ post smoke inhalation. A p value of $<0.05$ was considered statistically significant

presence of physiological dead space in lungs and the increased in gradient between these two values corresponds with ARDS severity [36, 37]. We observed an increase in the gradient $\left(\mathrm{PaCO}_{2}-\mathrm{ETCO}_{2}\right)$ from 7.67 at baseline to 14.21 at $48 \mathrm{~h}$ post smoke exposure. IL-6, one of the inflammatory cytokines involved in the 

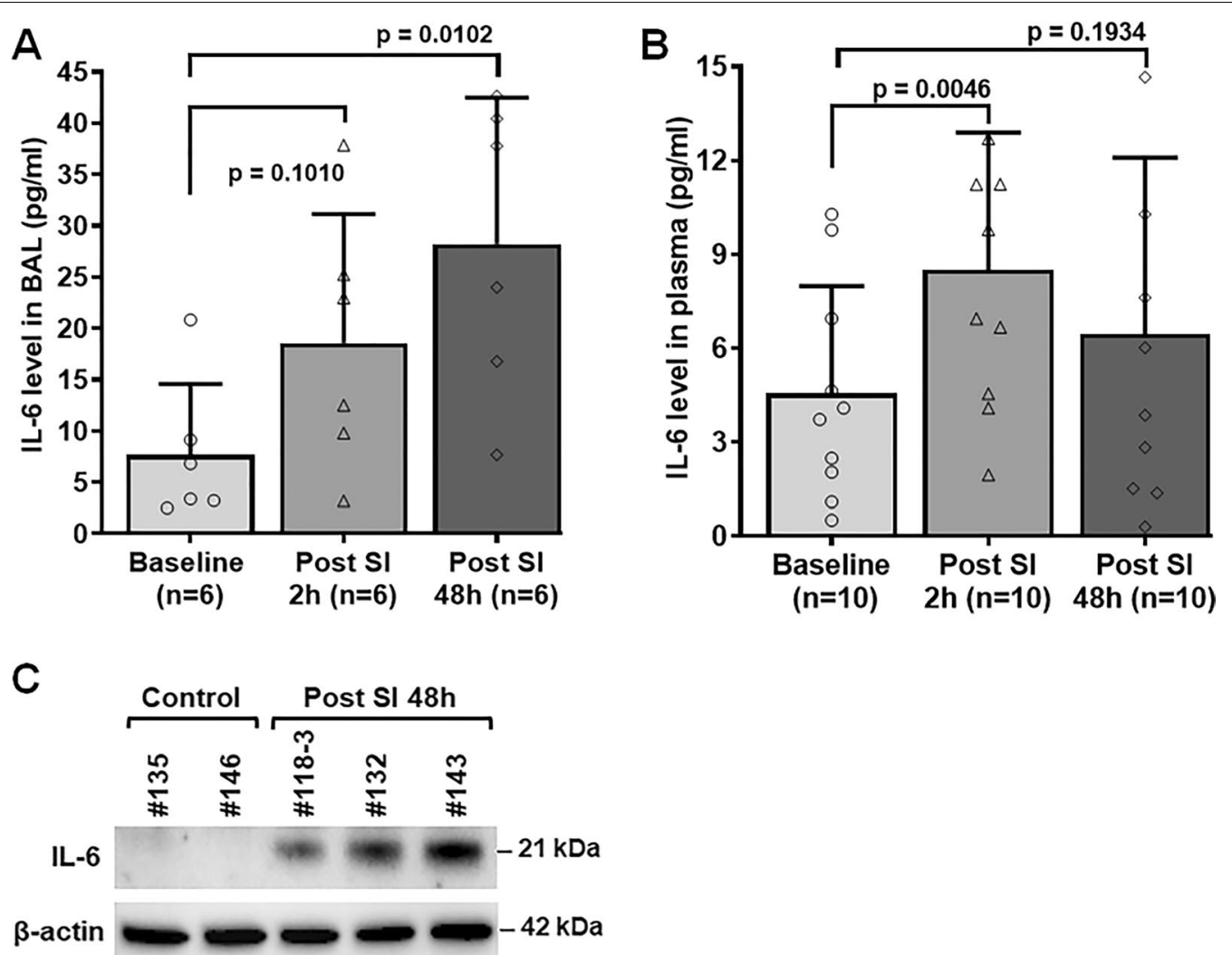

Fig. 8 Effect of smoke inhalation on IL-6 expression. A IL-6 expression level in BAL fluid samples of SI animals at baseline, $2 \mathrm{~h}$ and $48 \mathrm{~h}$ time points. B IL-6 expression level in plasma samples of $\mathrm{SI}$ animals at baseline, $2 \mathrm{~h}$ and $48 \mathrm{~h}$ time points. C Immunoblot analysis of IL-6 expression level in fresh frozen lung tissues of $\mathrm{SI}$ and control animals. A p value of $<0.05$ was considered statistically significant

development of ARDS started to rise $2 \mathrm{~h}$ time point in SI animals and sustained until $48 \mathrm{~h}$ in both plasma and BAL fluid samples. IL-6 expression level was also significantly upregulated in fresh frozen lung tissue samples of smoke exposed animals compared to control animals. We also observed a significant reduction of Ki67 positive cells in lung tissue of smoke exposed animals compared to control tissue indicating smoke exposure decreased normal lung parenchyma cell proliferation. In addition, evidence of significant lung tissue injury and inflammatory response to the injury were documented. These results indicated the deterioration of respiratory functions in the diseased lungs from smoke exposure.

Developing mimics of human ARDS in a large animal model such as pig has clear advantages, such as the ability to perform invasive procedures and serial blood analysis, and feasibility of documenting the respiratory function for an extended period of time. Moreover, monitoring the respiratory parameters in a mechanically ventilated animal allowed us to detail functional deterioration of the animal in a controlled environment after smoke inhalation. The detailed presentation of our model allows for others in the scientific community to independently confirm reproducibility, and hopefully use our model for investigations leading to clinical translation.

\section{Conclusion}

We developed, for the first time, a novel large animal isolated smoke inhalation-induced ARDS model which mimics human ARDS and lacks confounding variables such as cutaneous burn injury or intra-abdominal sepsis. This model will help in better understanding the pathophysiological mechanisms involved in the process of smoke inhalation-induced ARDS and aid in the development of novel therapeutic strategies.

\section{Abbreviations}

ABG: Arterial blood gas; ALl: Acute lung injury; ANOVA: Analysis of variance; ARDS: Acute respiratory distress syndrome; BAL: Bronchoalveolar lavage; BCA: Bicinchoninic acid; $\mathrm{CaO}_{2}$ : Arterial oxygen content; $\mathrm{CmvO}_{2}$ : Mixed venous oxygen content; CA: Carotid artery; CO: Cardiac output; CVP: Central venous pressure; ELISA: Enzyme-linked immunosorbent assay; $\mathrm{ETCO}_{2}$ : End-tidal carbon dioxide; $\mathrm{FA}$ : Femoral artery; $\mathrm{FiO}_{2}$ : Fraction of inspired oxygen; $\mathrm{HCO}_{3}$ : Hydrogen 
bicarbonate; HR: Heart rate; IL-6: Interleukin-6; MAP: Mean arterial pressure; PA: Pulmonary artery; PAP: Pulmonary artery pressure; $\mathrm{PaCO}_{2}$ : Partial pressure of carbon dioxide; $\mathrm{PaO}_{2}$ : Arterial oxygen partial pressure; PCWP: Pulmonary capillary wedge pressure; PEEP: Positive end-expiratory pressure; PIV: Peripheral intravenous catheter; $\mathrm{PmvO}_{2}$ : Partial pressure of mixed venous oxygen; PVDF: Polyvinylidene fluoride; RR: Respiratory rate; $\mathrm{SmvO}_{2}$ : Mixed venous oxygen saturation; $\mathrm{SpO}_{2}$ : Peripheral oxygen saturation; TBST: Tris-Buffered Saline, 0.1\% Tween ${ }^{\circledR} 20$ Detergent; TV: Tidal volume; W/D: Wet-to-dry weight.

\section{Acknowledgements}

We would like to thank the Institutional Animal Care staff at UNL for the help during the surgical procedures and for monitoring the animals included in this study.

\section{Authors' contributions}

Conceived and designed the study: KLB. Acquired, analyzed and interpret data: KLB, PDL, HRW. Performed histological analysis: EMD. Performed experiment with mechanically ventilated pig: KLB, PDL, HRW, AM, RRM. Wrote manuscript: KLB, PDL. All authors read and approved the final manuscript.

\section{Funding}

The study was financially supported by award FA4600-12-D-9000 from the Department of Defense U.S. Air Force.

\section{Availability of data and materials}

Data are available upon reasonable request from the corresponding author.

\section{Declarations}

\section{Ethics approval and consent to participate}

All the experiments involving animals were approved by University of Nebraska Lincoln (UNL) Institutional Animal Care and Use Committee (IACUC) (protocol \# 1674).

\section{Consent for publication}

Not applicable.

\section{Competing interests}

The authors declare no competing or financial interests.

\section{Author details}

${ }^{1}$ Department of Surgery, College of Medicine, University of Nebraska Medical Center, Omaha, NE 68198-3280, USA. ²Department of Mechanical and Materials Engineering, University of Nebraska-Lincoln, Lincoln, NE, USA. ${ }^{3}$ Department of Pathology and Microbiology, College of Medicine, University of Nebraska Medical Center, Omaha, NE, USA.

Received: 3 March 2021 Accepted: 28 June 2021

Published online: 07 July 2021

\section{References}

1. Máca J, Jor O, Holub M, Sklienka P, Burša F, Burda M, et al. Past and present ARDS mortality rates: a systematic review. Respir Care. 2017;62(1):113-22.

2. Phua J, Badia JR, Adhikari NKJ, Friedrich JO, Fowler RA, Singh JM, et al. Has mortality from acute respiratory distress syndrome decreased over time? Am J Respir Crit Care Med. 2009;179(3):220-7.

3. Bakowitz M, Bruns B, McCunn M. Acute lung injury and the acute respiratory distress syndrome in the injured patient. Scand J Trauma Resuscit Emerg Med. 2012;20:54-54.

4. Enkhbaatar P, Traber DL. Pathophysiology of acute lung injury in combined burn and smoke inhalation injury. Clin Sci. 2004;107(2):137-43.

5. Shirani KZ, Pruitt BAJ, Mason ADJ. The influence of inhalation injury and pneumonia on burn mortality. Ann Surg. 1987;205(1):82-7.

6. Ashbaugh D, Boyd Bigelow D, Petty T, Levine B. Acute respiratory distress in adults. Lancet. 1967;290(7511):319-23.

7. Force TADT. Acute respiratory distress syndrome: the berlin definition. JAMA. 2012;307(23):2526-33.
8. Matthay MA, Zemans RL. The acute respiratory distress syndrome: pathogenesis and treatment. Annu Rev Pathol. 2011;6:147-63.

9. Nash G, Blennerhassett JB, Pontoppidan H. Pulmonary lesions associated with oxygen therapy and artificial ventilation. N Engl J Med. 1967;276(7):368-74

10. Thille AW, Esteban A, Fernández-Segoviano P, Rodriguez J-M, Aramburu $J$-A, Vargas-Errázuriz P, et al. Chronology of histological lesions in acute respiratory distress syndrome with diffuse alveolar damage: a prospective cohort study of clinical autopsies. Lancet Respir Med. 2013;1(5):395-401.

11. Patel BV, Wilson MR, Takata M. Resolution of acute lung injury and inflammation: a translational mouse model. Eur Respir J. 2012;39(5):1162-70,

12. Voelker MT, Fichtner F, Kasper M, Kamprad M, Sack U, Kaisers UX, et al. Characterization of a double-hit murine model of acute respiratory distress syndrome. Clin Exp Pharmacol Physiol. 2014;41(10):844-53.

13. McLaughlin RF Jr, Tyler WS, Canada RO. Subgross pulmonary anatomy in various mammals and man. JAMA. 1961;175(8):694-7.

14. Glenny RW, Bernard SL, Luchtel DL, Neradilek B, Polissar NL. The spatialtemporal redistribution of pulmonary blood flow with postnatal growth. J Appl Physiol. 2007;102(3):1281-8.

15. Brogan TV, Mellema JD, Martin LD, Krueger M, Redding GJ, Glenny RW. Spatial and temporal heterogeneity of regional pulmonary blood flow in piglets. Pediatr Res. 2007;62(4):434-9.

16. Gushima Y, Ichikado K, Suga M, Okamoto T, Iyonaga K, Sato K, et al. Expression of matrix metalloproteinases in pigs with hyperoxia-induced acute lung injury. Eur Respir J. 2001;18(5):827-37.

17. Ballard-Croft C, Sumpter LR, Broaddus R, Alexander J, Wang D, Zwischenberger JB. Ovine smoke/burn ARDS model: a new ventilator-controlled smoke delivery system. J Surg Res. 2010;164(1):e155-62.

18. Barrow RE, Spies M, Barrow LN, Herndon DN. Influence of demographics and inhalation injury on burn mortality in children. Burns. 2004;30(1):72-7.

19. Dancey DR, Hayes J, Gomez M, Schouten D, Fish J, Peters W, et al. ARDS in patients with thermal injury. Intensive Care Med. 1999:25(11):1231-6.

20. Alpard SK, Zwischenberger JB, Tao W, Deyo DJ, Traber DL, Bidani A. New clinically relevant sheep model of severe respiratory failure secondary to combined smoke inhalation/cutaneous flame burn injury. Crit Care Med. 2000;28(5):1469-76.

21. Schmalstieg FC, Keeney SE, Rudloff HE, Palkowetz KH, Cevallos M, Zhou $X$, et al. Arteriovenous $\mathrm{CO}_{2}$ removal improves survival compared to high frequency percussive and low tidal volume ventilation in a smoke/ burn sheep acute respiratory distress syndrome model. Ann Surg. 2007:246(3):512-23.

22. Soejima K, Schmalstieg FC, Sakurai H, Traber LD, Traber DL. Pathophysiological analysis of combined burn and smoke inhalation injuries in sheep. Am J Physiol. 2001;280(6):L1233-41.

23. Kitamura Y, Hashimoto S, Mizuta N, Kobayashi A, Kooguchi K, Fujiwara I, et al. Fas/FasL-dependent apoptosis of alveolar cells after lipopolysaccharide-induced lung injury in mice. Am J Respir Crit Care Med. 2001:163(3):762-9.

24. Katalan S, Falach R, Rosner A, Goldvaser M, Brosh-Nissimov T, Dvir A, et al. A novel swine model of ricin-induced acute respiratory distress syndrome. Dis Model Mech. 2017;10(2):173-83.

25. Yilin Z, Yandong N, Faguang J. Role of angiotensin-converting enzyme (ACE) and ACE2 in a rat model of smoke inhalation induced acute respiratory distress syndrome. Burns. 2015;41(7):1468-77.

26. Wang T, Chen X, Zhang W, Xiang X, Leng C, Jia Q. Roles of macrophage stimulating protein and tyrosine kinase receptor $\mathrm{RON}$ in smoke-induced airway inflammation of rats. Int J Clin Exp Pathol. 2015;8(8):8797-808.

27. Fan E, Brodie D, Slutsky AS. Acute respiratory distress syndrome: advances in diagnosis and treatment. JAMA. 2018;319(7):698-710.

28. Julien M, Hoeffel JM, Flick MR. Oleic acid lung injury in sheep. J Appl Physiol. 1986;60(2):433-40.

29. Grotjohan HP, Van Der Heijde RMJL, Jansen JRC, Wagenvoort CA, Versprille A. A stable model of respiratory distress by small injections of oleic acid in pigs. Intensive Care Med. 1996;22(4):336-44.

30. Lewis JF, Tabor B, Ikegami M, Jobe AH, Joseph M, Absolom D. Lung function and surfactant distribution in saline-lavaged sheep given instilled vs. nebulized surfactant. Journal of Applied Physiology. 1993;74(3):1256-1264.

31. Muellenbach RM, Kredel M, Bernd Z, Johannes A, Kuestermann J, Schuster $F$, et al. Acute respiratory distress induced by repeated saline lavage 
provides stable experimental conditions for 24 hours in pigs. Exp Lung Res. 2009;35(3):222-33.

32. Guo Z, Lu G, Ren T, Zheng Y, Gong J, Yu J, et al. Partial liquid ventilation confers protection against acute lung injury induced by endotoxin in juvenile piglets. Respir Physiol Neurobiol. 2009;167(3):221-6.

33. Kabir K, Gelinas J-P, Chen M, Chen D, Zhang D, Luo X, et al. Characterization of a murine model of endotoxin-induced acute lung injury. Shock. 2002;17(4):300-3.

34. Le Floch A, Jourdes M, Teissedre P-L. Polysaccharides and lignin from oak wood used in cooperage: composition, interest, assays: A review. Carbohyd Res. 2015;417:94-102.

35. Fine $P$, Cass $G$, Simoneit B. Chemical characterization of fine particle emissions from the wood stove combustion of prevalent US tree species. Environ Eng Sci. 2004;21:705-21.
36. Belenkiy S, Ivey KM, Batchinsky Al, Langer T, Necsoiu C, Baker W, et al. Noninvasive carbon dioxide monitoring in a porcine model of acute lung injury due to smoke inhalation and burns. Shock. 2013;39(6):495-500.

37. Yousuf T, Brinton T, Murtaza G, Wozniczka D, Ahmad K, Iskandar J, et al. Establishing a gradient between partial pressure of arterial carbon dioxide and end-tidal carbon dioxide in patients with acute respiratory distress syndrome. J Investig Med. 2017;65(2):338-41.

\section{Publisher's Note}

Springer Nature remains neutral with regard to jurisdictional claims in published maps and institutional affiliations.
Ready to submit your research? Choose BMC and benefit from:

- fast, convenient online submission

- thorough peer review by experienced researchers in your field

- rapid publication on acceptance

- support for research data, including large and complex data types

- gold Open Access which fosters wider collaboration and increased citations

- maximum visibility for your research: over 100M website views per year

At BMC, research is always in progress.

Learn more biomedcentral.com/submissions 